\title{
Can a Transaction Tax or Capital Gains Tax smooth House Prices?
}

\author{
Nicole Aregger*, Martin Brown** and Enzo Rossi***
}

This version: 15 February 2011

\begin{abstract}
Motivated by the search for instruments of macroprudential policy, we examine the impact of transaction (Tobin) taxes and capital gains taxes on residential house price growth. We exploit the variation in taxation across 21 Swiss cantons, as well as within-canton changes in taxation over time. We relate these taxes to house price growth observed for 92 regions of the country during the period 1985 - 2009. Cross-section and panel results suggest that higher taxes on long-term capital gains have a substantial smoothing effect on house prices. Higher transaction (Tobin) taxes also smooth house prices. By contrast, penalty taxes on short-term capital gains seem to fuel excessive price growth when housing demand is vibrant. Our results suggest that taxes on real estate transactions and capital gains are not uniformly suitable as instruments of macroprudential policy.
\end{abstract}

Keywords: House prices, Tobin tax, Capital gains tax, Macroprudential policy JEL Codes: E32, H24, R21

\footnotetext{
* Aregger: Swiss National Bank, nicole.aregger@snb.ch

** Brown: University of St. Gallen, martin.brown@unisg.ch

*** Rossi: Swiss National Bank, enzo.rossi@snb.ch

Acknowledgements: We thank seminar participants at the Swiss National Bank and an anonymous referee for their helpful comments. We thank BAK Basel economics for kindly sharing data. Disclaimer: Any views expressed are those of the authors and do not necessarily reflect those of the Swiss National Bank.
} 


\section{Introduction}

As demonstrated powerfully in the recent crisis, developments in the housing market have a major effect on financial sector stability and real economic activity. The recent turbulences in the financial sector were at least partly caused by the build-up and subsequent collapse of property prices. ${ }^{1}$ In the past housing, booms tended to be followed by long lasting recessions and considerable output losses. ${ }^{2}$ The recent house price bust in various countries confirmed the potential danger housing price cycles can pose to financial stability.

A main lesson from the recent crisis is that policy-makers should pursue macroprudential policy to strengthen the financial system's resilience to economic downturns and limit the build-up of risks to financial stability. ${ }^{3}$ In most economies, macroprudential policy frameworks are at an early stage of development, and the evidence for their effectiveness is tentative. ${ }^{4}$ One macroprudential instrument authorities may use to limit or pre-empt real estate price booms is a (variable) cap on loan-to-value ratios of mortgages. ${ }^{5}$ Another instrument is taxation of real estate acting as an automatic stabilizer for housing prices. $^{6}$

${ }^{1}$ Cf., e.g., Borio and Disyatat (2009). Reinhart and Rogoff (2008) set out some parallels between America's subprime crisis and 18 previous post-war banking crises in the rich world. They show that banking crises have a common pattern. Each blow-up is preceded, inter alia, by rising home and equity prices. Hilbers et al. (2001) show empirically that unbalanced developments in real estate markets can be an important factor contributing to vulnerabilities and possibly crises in the financial sector.

${ }^{2}$ Cf. IMF (2003), Ahearne et al. (2005), Leamer (2007), Claessens et al. (2008), IMF (2009), Jannsen (2010).

${ }^{3}$ Cf. Milne (2009), CGFS (2010), and Jordan (2010). Bank of England (2009) discusses possible ways to make a macroprudential policy regime operational.

${ }^{4}$ According to Allen and Carletti (2010) loose monetary policy is one of the main causes for real estate bubbles. Thus one of the most important macroprudential measures should be constraining monetary policy so that it does not trigger bubbles.

${ }^{5}$ Cf. Goodhart (2009), Allen and Carletti (2010).

${ }^{6}$ Cf. Posen (2009). Similarly, Jeanne (2008) proposed a counter-cyclical Pigouvian tax on debt, including mortgage debt, to internalize the negative externality which individual borrowers produce on systemic risk. Cf. Jeanne and Korinek (2010) for a dynamic model in which a Pigouvian tax manages credit booms and busts. 
In this study we examine the effectiveness of taxes on real estate transaction values (Tobin tax) and capital gains as macroprudential instruments to smooth price growth in the residential housing market. We exploit the variation in taxation across 21 Swiss cantons as well as within-canton changes in taxation over time during the period 1985 - 2009. We relate excessive house price growth in 92 regions to the taxation of real estate transaction values and capital gains in the canton the region is located in.

In cross-sectional and panel regressions we find that a tax on long-term capital gains smoothes house prices. Cantons with higher taxes on long-term capital gains display less volatility of house price growth over our observation period. Moreover, in periods of high fundamental demand for housing, cantons with higher taxes on long-term capital gains experience less excessive price growth. By contrast, we find that a penalty tax on short-term capital gains fuels excessive price growth when housing demand is strong. Finally, our results suggest that cantons with higher transaction (Tobin) taxes experience less excessive price growth.

Our results suggest to policy makers that Tobin taxes and capital gains taxes are not uniformly suitable as instruments of macroprudential policy. In particular, due to lock-in effects for existing home-owners, the use of penalty taxes on short-term capital gains seems to be counterproductive to the objective of systemic stability. Taxes on long-term capital gains and transaction values, by contrast, seem to be viable instruments for macroprudential policy.

Switzerland is a particularly interesting country in which to study the effects of real estate taxes for two reasons. First, given the substantial variation in taxation of real-estate transaction values and capital gains across its cantons, Switzerland provides a unique opportunity to study how taxes impact on residential house price growth in an homogeneous macroeconomic environment with an integrated banking sector and common legal system. By comparison, cross-country studies of regulation, taxation and house prices are marred by 
(unobservable) macroeconomic and structural characteristics across countries. Second, Switzerland has in the past experienced a financial sector crisis due to a real estate boom. The sharp rise in real estate prices in the 1980s, followed by a slump in prices in the early 1990s, led to substantial loan losses as well as a restructuring of the Swiss banking sector. The large Swiss banks alone wrote off CHF 30 billion or nearly 13\% of their loan volume. Nearly half of the 200 regional banks, a group consisting of small locally-based institutions, did not survive the crisis and lost their independence. From 1990 to 1995 the number of banks operating in Switzerland dropped from 625 to 413.

The rest of the paper is organized as follows. Section 2 offers a review of related work. Section 3 presents our data and empirical methodology. Section 4 presents our results and section 5 concludes.

\section{Related Literature}

There is an extensive theoretical and empirical literature examining the impact of housing tax policy on housing decisions (cf., for instance, Smith et al. 1988 and Nakagami and Pereira 1995). By contrast, only little research has been devoted specifically to the effects of taxation on price developments in real estate markets. In this section we focus on those contributions which study the impact of transaction (Tobin) taxes and capital gains taxes on house price dynamics. This literature provides ambiguous predictions and inconclusive empirical findings on the relationship between transaction taxes, capital gains taxes and house price developments. 


\subsection{Theoretical studies}

The idea to tax financial transactions in order to reduce asset price volatility was introduced by Keynes (1936) for stock exchanges and Tobin (1978) for currency markets. Stiglitz (1989) argues that a transaction tax can reduce speculative trading and price volatility in asset markets. However, the subsequent theoretical literature suggests that transaction taxes may amplify rather than smooth price fluctuations, for instance by reducing the liquidity of asset markets (cf., e.g., Hau 2006). The effect of a capital gains tax on asset price volatility is also theoretically ambiguous (cf. Fuest et al. 2004 for an overview). The model of Stiglitz (1983), for example, shows that such a tax may increase volatility. In his model, a capital gains tax leads households to postpone the realization of capital gains (lock-in effect ${ }^{7}$ ) and bring forward capital losses, lifting asset prices when there is upward price pressure and reducing them when the prices of assets are low.

With respect to the housing market, Englund (1986) suggests that capital gains taxes on real estate can exacerbate price dynamics by giving rise to lock-in effects which inhibit trade. ${ }^{8}$ He considers in a two-period overlapping-generations (OLG) model whether capitalgains taxation increases or decreases market demand for owner-occupied housing. In a growing economy an increase in the capital gains tax lowers housing demand for low tax rates, reducing price dynamics. However, as soon as the tax rate reaches a critical value, the household chooses to stick to the same house for both periods and demand picks up. The general conclusion is that a high capital-gains tax may not dampen, but actually accelerate the development of house prices.

\footnotetext{
${ }^{7}$ A homeowner postponing the realization of a capital gain is hit by a lower tax rate in present value terms.

${ }^{8}$ Englund (1985) compares taxation of capital gains on realization with taxation on accrual in the context of owner-occupied housing in an infinite-horizon model. Taxing capital gains upon realization rather than as the gains accrue boils down to giving the taxpayer an interest-free loan, effectively taxing capital gains at a lower rate than other income, thereby violating the principles of comprehensive income taxation. Cf. Diamond (1975) and King (1977).
} 
Fuest et al. (2004) also use a two-period OLG model to examine whether capital gains taxes increase or decrease fluctuations in house prices. They argue that households who buy their real estate in a boom are likely to suffer a capital loss. By contrast households buying their real estate in a recession are likely to make a capital gain when selling it. A capital gains tax reduces the expected losses of those buying in the boom and reduces the gains of those buying during recession. As a consequence the former will pay more while the latter will pay less so that real estate prices increase even further in booms and fall even more in recessions.

There is to our knowledge no theoretical paper which explicitly models the implications of a transaction tax (Tobin tax) on house price dynamics. Lundborg and Skedinger (1999) show in a search model with endogenous house prices that a transaction tax unambiguously leads to lock-in effects. Their model does not consider the implications of this effect for house prices in a dynamic setting. However, according to the model of Englund (1986) mentioned above, lock-in effects in the real estate market would amplify house-price volatility.

\subsection{Empirical studies}

Hoyt and Rosenthal (1992) simulate the effects on housing demand from a simultaneous increase in the capital gains tax rate and a lowering of federal marginal income tax rates, consistent with the US Tax Reform Act in 1986 (TRA86). Rollover provisions in the US tax code enable homeowners to avoid paying tax on the capital gains from the sale of their home if they purchase another home of equal or greater value within a certain period of when they moved. Because of these tax provisions households face a different price of housing depending on whether they purchased a more (buy up) or less expensive house (buy down). Against this legal background, the TRA86 increased the difference in the price of 
housing services between buying up versus buying down. On the one hand an increase in the capital gains tax rate raised the penalty for buying down, on the other lower marginal tax rates raised the user cost of owner-occupied housing. As a result housing demand would fall with a decrease in the capital gains tax rate as additional previous homeowners buy down.

Lundborg and Skedinger (1998) provide evidence on the size of the lock-in effect due to capital gains taxation based on survey data of 6,000 Swedish home owners during the 1980s. Their results suggest that capital gains taxation reduces the probability of buying down for households with too high a housing consumption. However, capital gains taxes do not appear to have lock-in effects for households which want to buy up, i.e. those whose income has risen or family size increased and thus for whom consumption is regarded as too small.

Rosen et al. (1984) examine how capital gains taxes affect the risk associated with home ownership. They estimate the impact of capital gains taxation on the tenure choice during the second half of the 1970s, taking into account the uncertainty about the user cost of housing and assuming perfect supply elasticity. Based on US time series and cross sectional data they show that capital gains taxes may, on balance, increase the proportion of owneroccupiers. Two opposing effects are working. On the one hand, the expected cost of owning increases. On the other hand, the forecast error variance of the user cost is sufficiently reduced to dominate.

Closest to our study, Sheffrin and Turner (2001) examine the impact of capital gains taxes across different metropolitan regions with varying patterns of house price dynamics. ${ }^{9}$ Using household data from 1985 to 1995 they find that households would, on the one hand, benefit from a capital gains tax by reducing the volatility of housing prices. On the other hand

\footnotetext{
${ }^{9}$ From a methodological point of view the panel analysis based on US interstate variation in capital gains taxation during 1979-90 provided by Bogart and Gentry (1995) is the most similar to our approach. In contrast to our paper which looks at the impact on house price dynamics, Bogart and Gentry look at the relation between capital gains tax rates and capital gains realizations. They find that capital gains realizations are negatively related to capital gains tax rates, suggesting lock-in effects from capital taxation.
} 
capital gains taxes increase the user cost. On balance, and contrary to Rosen et al. (1984), the latter effect dominates, leaving households on average worse off. However, the results vary strongly by metropolitan areas and over time. Households in high-volatility areas would benefit from capital taxes whereas homeowners in high-appreciation cities would be hurt.

To our knowledge there is no empirical study which examines the impact of a Tobin tax on house price dynamics. As surveyed by Hau (2006), the empirical evidence on the relation between transaction costs and asset price volatility is inconclusive. Based on his panel regressions using data from the French stock exchange between 1995 and 1999 he argues that security transaction taxes in particular are likely to increase volatility.

Our study complements the literature presented above by examining the impact of crosssectional and time-variation in transaction and capital gains taxes on house price growth. Compared to the above studies on US and Swedish data, our analysis benefits from the fact that we observe varying levels of taxation across regions within a country and over a long period of time. Compared to potential cross-country studies on taxation our analysis has the advantage of studying a sample of regions which have a harmonized macroeconomic policy, an integrated banking system and a common legal environment.

\section{Data and methodology}

\subsection{House prices}

Our analysis is based on house prices observed for 92 regions in Switzerland over the period 1985 - 2009. Each MS-region (MS = spatial mobility) is made up of several municipalities which together form a local labor market. A graphical representation as well as a list of all MS-regions and their attribution to the Swiss cantons are provided in Appendix 
A1. The MS-regions covered in this study account for $87 \%$ of the Swiss population and an estimated $87 \%$ of GDP in 2008. ${ }^{10}$ For each MS-region we observe an annual index of nominal prices for single-family houses and condominiums separately. Both indices are measured on a hedonic basis to account for quality changes. We calculate average annual price growth for single-family houses (Price growth SFH) and condominiums (Price growth $C O N$ ) for each of the following five periods: 1985-1989, 1990-1994, 1995-1999, 2000-2004, 2005-2009. Table 1 provides definitions and sources of all variables employed in our analysis.

\section{[Table 1 here]}

Figure 1 displays the variation of house price growth across time and MS-regions in our sample. Three important observations can be made from this figure. First, the five periods for which we calculate house-price growth correspond to five distinct phases of house-price movements. Between 1985 and 1989 prices for single-family houses rose by 3.5\% per year in nominal terms (median). In real terms this corresponds to a cumulative increase of $7 \%$ for this period. At the beginning of the 1990s price growth came to a halt. Nominal prices for singlefamily homes remained stable between 1990 and 1994, implying a cumulative real decline of more than 15\%. Between 1995 and 1999 both nominal and real prices for single-family houses remained stable. Between 2000 and 2004 nominal prices for single-family houses rose by $0.8 \%$ per year, implying a modest cumulative real growth of $3 \%$ for this period. From 2005 onwards price growth accelerated, reaching 3.5\% per year in nominal terms and a cumulated real price growth of 13\% between 2005 and 2009.

\footnotetext{
${ }^{10}$ We include in our analysis the four MS-regions (Laufental (25), La Broye (93), La Chaux-de Fonds (103) and Murten (42)) for which a share of 21 to 40 percent of the population in these MS-regions is living in communes belonging to one or more other cantons than the canton listed in Table A1. All our results are confirmed in robustness tests dropping these four MS-regions.
} 
[Figure 1 here]

The second observation from Figure 1 is that the price growth of condominiums displays stronger variation across time than that of single-family homes. In the periods of strongest price increases median price growth for condominiums exceeds that of single-family houses by $1.7 \%$ per year (1985-1989) and $0.6 \%$ per year (2005-2009), respectively. By contrast in the two periods of real price decline (1990-1994, 1995-1999) the prices of condominiums displayed lower median growth than those of single-family houses.

The third observation from Figure 1 is that in each of the five periods there is substantial regional variation in price growth. Between 1985-1989, for example, nominal price growth for single-family homes grew by less than $0.4 \%$ per year in the four slowest growing MS-regions, while price growth exceeded 7\% per year in the four fastest growing MS-regions. In the period 2000-2004 nominal prices for single-family houses fell by more than $2 \%$ per year in the two slowest growing regions, while they increased by more than $5 \%$ per year in the three fastest growing regions. The most recent period 2005-2009 has seen an even wider dispersion in regional house price developments. Nominal prices for single-family houses rose by less than $1 \%$ per year in the two slowest growing MS-regions, while price growth exceeded 8\% per year in the three fastest growing MS-regions. The figure shows that the two periods of real price depreciation (1990-1994, 1995-1999) also display substantial regional variation in price developments. 


\subsection{Taxation of real estate capital gains and transaction values}

The taxation of real-estate capital gains and transaction values differs strongly across Swiss cantons. ${ }^{11}$ We collected information on the tax regimes and tax rates from the authorities of the 26 cantons over the period 1980-2005. Appendix A2 provides an overview of the current tax regimes of the capital gains tax and transaction tax (Tobin tax) by canton. Due to missing data only 21 cantons are included in our sample. ${ }^{12}$

We employ three indicators of taxation in our empirical analysis. The first two tax indicators measure the taxation of real estate capital gains by canton. ${ }^{13}$ For private households, each canton levies a real-estate capital gains tax, which is independent of the income or wealth status of the tax payer. ${ }^{14}$ The capital gains tax is levied each time a gain on real estate has been realized and is due by the seller. The gain is computed as the selling price (transaction value) minus the original purchasing price plus the value increasing expenditures by the owner. In most of the cantons the tax rate is progressively related to the level of the capital gain, while in each canton there is an inverse relationship between the tax rate and the

${ }^{11}$ Our analysis focuses on the taxation of capital gains and transaction values as we expect these taxes to influence house price growth. We do not examine the taxation of property values or (imputed) income, as we expect these taxes to affect the level of house prices rather than their growth. In Switzerland the holding of realestate, i.e. the property value and the income derived from it, are taxed. The imputed rent of owner-occupied housing is considered to be part of household income and is therefore subject to the ordinary income tax, while housing value is subject to wealth tax. Housing expenses such as mortgage interest can be deducted from income taxes while the mortgage itself from the wealth tax. In most cantons also maintenance costs or insurance premiums can be deducted from the income tax (SFTA 2010a, 2010b).

${ }^{12}$ There is no tax data available from the canton Zug and St. Gallen, and data for Jura and Solothurn is only available for a limited period. Data on mortgage interest rates for Appenzell A.Rh. are missing.

${ }^{13}$ In Switzerland taxes are levied at the federal, at the cantonal and communal level. Income taxes are levied at all three state levels. Wealth taxes and property taxes are cantonal and communal, but the latter do not exist in all cantons. Capital gains taxes are cantonal and/or communal. The capital gains tax on movable private wealth was abolished in all cantons. The canton Graubünden was the last canton which abolished this tax in 1997 (SFTA 2010d).

${ }^{14}$ For companies, gains on real estate are taxed either according to the corporate income tax rate or the above mentioned gains tax. As 89\% of all residential buildings in Switzerland are owned by private persons we focus our analysis on cross-canton differences in the taxation of gains by private persons. Concerning private persons one has to distinguish between private wealth and business assets. On private wealth the capital gains tax is levied and on real estate that belongs to the business assets, the income tax is levied. 
duration the real estate was held. ${ }^{15}$ This tax pattern aims to penalize short-run price speculation. ${ }^{16}$ Our two indicators capture the level and inverse time progression of the capital gains tax. The variable Capital gains tax measures the top marginal tax rate applicable to real estate capital gains if the property is sold after holding it 5 years. The variable Speculation multiplier measures by how much the top marginal rate on real-estate capital gains is multiplied if the residential property is sold less than one year after it has been purchased.

Our third tax indicator measures the transaction tax (Tobin tax) which, in addition to capital gains taxes, is levied every time real estate changes hand. ${ }^{17}$ It is applied to the transaction value, i.e. the selling price. In most cantons the tax is proportional to the realestate value and due by the buyer. ${ }^{18}$ The variable Transaction tax captures the top marginal rate of the tax on transaction values by canton. ${ }^{19}$

[Table 3 here]

We collected our three tax indicators at five points in time: 1985, 1990, 1995, 2000 and 2005. Table 3 shows that there is substantial variation across the cantons and over time for each indicator. In 1985, for example, the Capital gains tax varied from less than $20 \%$ in the cantons of Obwalden and Vaud to $40 \%$ and more in Thurgau, Schaffhausen and Valais.

${ }^{15}$ Unlike other countries the tax code makes no explicit distinction between buying up and buying down transactions. However, like in other countries, cantonal tax rules provide for postponement of the tax liability if the sales revenue of owner-occupied housing is used to purchase another property within some period of time (roll-over provision). This amounts to an implicit tax-exemption on "buying up".

${ }^{16}$ SFTA (2010c).

${ }^{17}$ Transaction taxes are, similar to capital gains taxes, levied at the canton and/or municipal level.

${ }^{18}$ SFTA (2010e). Some cantons apply progressive tax rates, in some cantons the transaction tax has the form of a fee and some cantons do not have such a tax anymore. Also, some cantons split the tax between the buyer and seller. Cf. Appendix A2 for details. The majority of cantons levy a lower rate for transactions within families (descendants, spouses, etc.). However, as such intra-family sales are quite rare in Switzerland, we focus on the regular transaction tax rate.

${ }^{19}$ In robustness checks we calculated our three tax indicators based on five standard real estate transactions. The qualitative findings are the same. 
Between 1985 and 2005 eight cantons raised this tax (e.g. Basel-Stadt from 32\% to 48\%), while four cantons reduced it (e.g. Valais from $40 \%$ to 26\%). The Speculation multiplier on short-term real estate gains varied in 1985 from 1, i.e. no multiplier (e.g. in Vaud), to 2, i.e. a doubling of the capital gains tax (e.g. in Basel-Land). Between 1985 and 2005 the speculation multiplier was increased in six cantons, while it was reduced in seven cantons. Finally, the Transaction tax rate varied in 1985 from less than 0.5\% in Aargau and Uri to 4\% in Fribourg and Neuchâtel. Between 1985 and 2005 this tax shows the fewest changes within cantons; it was raised in two cantons and reduced in five others, for example in Zurich, where it was abolished altogether.

\subsection{Estimating abnormal house price growth}

The first step of our empirical analysis is to estimate abnormal house price growth by MS-region and period. To this end, we relate nominal price growth to regional indicators of housing demand and supply during each period. We estimate the following model:

$$
\begin{aligned}
P_{r, t}=\alpha_{r}+\beta_{1} \cdot X_{r, t}+ & \varepsilon_{r, t}, \\
& \text { whereby } P_{r, t} \in\{\text { Price growth SFH; Price growth CON }\}
\end{aligned}
$$

In this model $X_{r, t}$ is a vector of time-variant indicators of housing demand and supply growth at the region level. MS-region fixed effects $\alpha_{r}$ account for time-invariant, structural differences across MS-regions, which may affect the housing market.

We employ four indicators to control for fundamental dynamics in housing demand and supply across MS-regions and our periods of observation. ${ }^{20}$ The variable Population growth measures average annual population growth per MS-region and period. Population growth includes immigration which has been shown to affect house prices in Switzerland and

\footnotetext{
${ }^{20}$ Steiner (2010) considers these indicators to be key determinants of Swiss housing dynamics at the country level.
} 
other developed countries (cf., e.g., Degen and Fischer 2009 and Saiz 2007). The variable Income growth measures average (nominal) annual growth of per capita income per MSregion and observation period. Our indicator of growth in housing supply is the net growth of the housing stock (Housing stock growth). For this indicator we also take annual data per MSregion and calculate average growth per MS-region per observation period. As housing supply has been found to have a lagged impact on house price dynamics (Steiner 2010) we employ the lagged value of this variable in our analysis. ${ }^{21}$ Finally, we take account of differences in lending conditions across time and regions. Previous research (Bolliger and Cecchin 2009) shows that there are significant regional differences in mortgage loan pricing within Switzerland. We control for this variation by including the variable Mortgage rate, which measures the average interest rate offered on new mortgages at the canton level. ${ }^{22}$ Table 2 provides summary statistics by period for our indicators of housing demand and supply.

[Table 2 here]

In addition to these direct measures of growth in housing demand and supply we control for structural differences across the regions which may affect the level of housing demand and supply and the way house prices react to exogenous shocks. The MS-regions differ for example in terms of their urban/rural structure ${ }^{23}$, their attractiveness for tourism, the

\footnotetext{
${ }^{21}$ For the period 2005-2009 we use average annual growth in housing for the period 2000-2004, for the period 2000-2004 we use net growth housing stock for the period 1995-1999, etc. For the period 1985-1989 we use net growth in housing stock in 1984 as we have data on the housing stock only from 1984 onwards.

${ }^{22}$ Due to missing data for 2009, our indicators of Population growth, Income growth, and Mortgage rate for the period 2005-2009 are based on 2005-2008 averages.

${ }^{23}$ The Swiss Federal statistical office classifies each municipality into one of four types: 1=Central city of an agglomeration, 2=Agglomeration, 3=Isolated city, 4=rural.
} 
availability of vacant premises or land for building purposes ${ }^{24}$, or home-ownership rates ${ }^{25}$. While these structural variables differ substantially across the MS-regions, they hardly vary over time, so that they are captured well by MS-region fixed effects.

From Model [1] we derive two indicators of abnormal price growth. Our first measure is the residual price growth per MS-region and period estimated from model [1] $\operatorname{resid}_{r, t}=P_{r, t}-\hat{P}_{r, t}$, whereby $\hat{P}_{r, t}$ is the fitted value of the regression. We calculate this indicator for single-family house prices (Residual growth SFH) and condominium prices (Residual growth CON) separately. Our second measure of abnormal price growth is a crosssectional measure of house price volatility per MS-region over the entire observation period. Our indicator of volatility is the mean absolute residual by MS-region from model [1], i.e. $\operatorname{Vol}_{r}=\frac{1}{T} \sum_{t=1}^{T}\left|P_{r, t}-\hat{P}_{r, t}\right|$. We calculate this indicator of volatility also for single-family house prices (Volatility SFH) and condominium prices (Volatility CON) separately.

\subsection{Taxes and abnormal house price growth}

In the main step of our empirical analysis, we relate our indicators of abnormal house price growth, estimated from model [1], to our indicators of real-estate taxation presented in section 3.2. In our first approach we estimate a cross-sectional model of the volatility of house-price growth by MS-region. As captured in model [2] we relate our indicator of volatility per MS-region to canton-level taxes on real estate transactions $T_{c}$. (Capital gains

\footnotetext{
${ }^{24}$ Zürich has the lowest housing vacancy rate with $0.03 \%$, while the MS-region "Glarner Hinterland" has the highest rate with $3.82 \%$ (in 2008).

${ }^{25}$ The home ownership rate in Switzerland, defined as the ratio of owner-occupied dwellings to total occupied dwellings, is $35 \%$. Owner-occupied dwellings consist of condominium owned dwellings (22.8\%), sole owned houses (66.5\%) or joint owned houses (10.7\%) (SFSO 2004). Bourassa and Hoesli (2006) analyse the reasons for the country's low ownership rate by international standards.
} 
tax, Speculation multiplier and Transaction tax). For each tax indicator we calculate the mean across our five observation points (1985, 1990, 1995, 2000, 2005). We control for structural characteristics of MS-regions $Y_{r}$ which may affect the dynamics of the housing market. In particular we distinguish Urban MS-regions from rural ones, and MS-regions which are Tourism destinations from those which are not. Our conjecture is that urban and touristic regions display stronger volatility of price growth. Finally we control for canton-level policy indicators $Z_{c}$ which may also affect house price dynamics. In particular, we control for the Income tax rate which varies strongly across Swiss cantons, and which has been argued to exert a strong influence on house prices (Bourassa and Hoesli, 2006). Table 1 provides definitions and sources of the control variables employed in model 2, while Table 2 provides summary statistics.

[2] $\quad \mathrm{Vol}_{r}=\alpha+\beta_{1} \cdot T_{c}+Y_{r}+\varepsilon_{r}$

$$
\text { whereby } \mathrm{Vol} \in\{\text { Volatility SFH; Volatility CON }\}
$$

In our second approach we use panel data to examine whether taxes on real estate transactions reduce abnormal price growth when there is a strong fundamental demand for housing. The impact of the capital gains tax and the Tobin tax under strong housing demand is arguably most interesting from the viewpoint of macroprudential policy. As captured by model [3] we relate residual price growth by MS-region and period (1985-1989, 1990-1994, 1995-1999, 2000-2004 and 2005-2009) to the taxation of real estate transactions in that period in the canton where an MS-region is located $T_{c, t}$. To capture the differential impact of real estate taxes in cantons with strong demand we interact our indicators of real estate taxation with the variable Demand growth $\left(D_{r, t}\right)$, which is calculated as the sum of (per capita) Income 
growth and Population growth. Remember that model [1] includes both the main effects of Population growth and Income growth. As a consequence, when we examine the residuals from model [1] as our dependent variable in model [3] we can exclude these variables. ${ }^{26}$ Model [3] includes fixed effects $\left(\alpha_{c}\right)$ for each canton to account for structural differences across cantons which may be correlated with the taxation of real estate transactions.

[3]

$$
\operatorname{resid}_{r, t}=\alpha_{c}+\beta_{1} \cdot T_{c, t}+\beta_{2} \cdot D_{r, t} * T_{c, t}+\varepsilon_{r, t},
$$

whereby resid $\in\{$ Residual growth SFH; Residual growth CON $\}$

In model [3] we relate excessive price growth by MS-region and period to the tax conditions in the canton where an MS-region is located at the start of each period (1985, 1990, 1995, 2000, 2005). We choose this approach in order to mitigate concerns of the endogeneity of tax policy. The tax rates set by the cantonal authorities could be endogenous to expected price growth, and this could bias our results in either direction. On the one hand, cantons which expect a strong growth in real-estate prices may hike their rates in advance in order to increase their tax revenue or to smooth house prices. Alternatively, due to the strong tax competition in Switzerland (cf., e.g., Brülhart and Jametti 2008) those cantons which expect higher future real estate gains and transaction values may actually reduce their tax rates. By using tax rates which are elicited at the beginning of a five year observation period, we hope to mitigate as much as possible these potential biases arising from forward-looking tax authorities.

\footnotetext{
${ }^{26}$ Rather than estimate model [3] with Residual growth SFH and Residual growth CON as dependent variables, we could alternatively estimate model [1] with Price growth SFH and Price growth CON as explanatory variables adding our three tax indicators Capital gains tax, Speculation multiplier, Transaction tax, as well as their interaction terms with Demand growth. For expositional reasons, i.e. to emphasize that we are examining excessive price growth we choose the former approach.
} 
To further account for the potential endogeneity of tax policy, we conduct for models [2] and [3] subsample analyses in which we exclude all MS-regions which may exert a significant impact on the tax policy in their canton. First, we limit our analysis to those cantons which are made up of at least three MS-regions. From these larger cantons we also drop all MS-regions which account for more than $20 \%$ of the population of the canton they are located in (averaged over our observation period).

While we attempt to tackle the endogeneity of tax policy, we only partly account for other correlations in our data, which may bias the results. First, we treat prices in each MSregion as independent observations, although it is highly likely that there are price spill-overs across the borders of MS-regions. We attempt to control for such spill-overs, at least within cantons, by clustering our error-terms in models [1-3]. Second, in our estimation of excess price growth (model 1) some of our explanatory variables, e.g. Population growth or Income growth may be endogenous to Price growth. We do not account for this potential endogeneity as we are not primarily interested in the estimators of these variables and we lack strong instruments for them.

\section{Results}

\subsection{Abnormal house price growth}

Table 4 presents our estimation of fundamental house price growth according to model [1]. We report results for single-family houses (Price growth $S F H$ ) in columns (1-2) and condominiums (Price growth CON) in columns (3-4). For both housing categories we present our preferred model which includes MS-region fixed effects and benchmark these results against a model without fixed effects. The estimated coefficients suggest that the effects of our indicators of housing demand and supply are robust across these two 
specifications. However, the R-squared suggests that the specification with MS-region fixed effects is more accurate, confirming the presence of structural differences in the housing market across the regions.

\section{[Table 4 here]}

As far as single-family homes are concerned we find, as expected, a significant positive effect of population growth and income growth on price growth, while the effect of housing supply and the mortgage rate are significantly negative. The effects of our demand and supply indicators are not only statistically significant, but also economically meaningful. A $1 \%$ increase in Population growth raises single-family house price growth by roughly $0.6 \%$ per year, while a $1 \%$ increase in per capita Income growth raises price growth by $0.9 \%$.

The price growth of condominiums reacts (even) stronger to changes in demand than the prices for single-family homes. A $1 \%$ increase in population growth raises condominium price growth by $0.8 \%$, while a $1 \%$ increase in per capita income raises price growth by $2 \%$ per year. The price growth of condominiums also reacts stronger to changes in housing supply and interest rates. In line with our predictions the coefficients for Housing stock growth and Mortgage rate are both negative in all specifications. They are economically larger and more precisely estimated for condominium price growth than for single-family house price growth.

[Figure 2 here]

Based on the estimations in columns $(2,4)$ of Table 4 we calculate our measures of abnormal house price growth, i.e. Residual growth SFH and Residual growth CON on the one hand, Volatility SFH and Volatility CON on the other. Figure 2 displays the regional and time 
variation of Residual growth SFH and Residual growth CON. The figure suggests that the variation in aggregate house price growth over time observed in Figure 1 is strongly related to fundamental determinants of housing demand and supply. The median of Residual growth CON, for example, ranges only from $-1.96 \%(1995-1999)$ to $1.8 \%(2000-2004)$. The median of Residual growth SFH displays even less variation across time, ranging from -0.75\% (19951999) to 1\% (1985-1989). By contrast, within each period we find substantial variation in residual price growth across MS-regions. For example, the difference between the highest and lowest value of Residual growth SFH or Residual growth CON exceeds 6 percentage points in each period.

[Figure 3 here]

Figure 3 shows that the volatility of house price growth (Volatility SFH, Volatility $C O N$ ) varies substantially across MS-regions. In the MS-region with the highest volatility of price growth of single-family houses (condominiums) actual price growth deviates from estimated price growth by more than 3\% (4\%) per year. In line with anecdotal evidence on regionally concentrated house price bubbles in Switzerland the MS-regions with the highest volatility of price growth are located in and around the financial centers of Zurich and Geneva. By contrast, the MS-regions with the lowest volatility of price growth (less than 1\%) are mainly rural, non-tourist regions. In our sample of 92 MS-regions Volatility SFH and Volatility CON are highly correlated (0.68, $p<0.01)$. 


\subsection{Taxes and the volatility of house price growth}

In this section we provide a cross-sectional analysis of the relation between the volatility in house price growth (Volatility $S F H$, Volatility $C O N$ ) and the taxation of real estate transactions (Capital gains tax, Speculation multiplier, Transaction tax). In Table 5 we report estimates for model [2].

\section{[Table 5 here]}

The analysis reported in Table 5 suggests that the taxation of real estate capital gains or transactions values does not affect the volatility of price growth for single-family houses (Volatility SFH). In column (1) we report a specification which includes only our real estate tax indicators (Capital gains tax, Speculation multiplier, Transaction tax), while the specification in column (2) controls for additional structural characteristics of MS-regions which may affect the demand and supply growth of housing (Urban, Tourism, Income tax). None of our tax indictors displays a significant coefficient in either specification.

By contrast, we find some evidence that the taxation of capital gains smoothes the volatility in the growth of prices for condominiums. Columns $(4,5)$ suggest that there is a significant negative relationship between the Capital gains tax and Volatility CON, while there is no significant effect of Speculation multiplier or Transaction tax. The estimated coefficient of Capital gains tax is sizeable from an economic perspective. Raising the capital gains tax on housing by $1 \%$ would reduce the volatility of price growth by $0.02 \%-0.03 \%$. Thus going from the canton with the lowest capital gains tax (Obwalden $=16.5 \%$ averaged over our observation period) to the canton with the highest (Schaffhausen $=46 \%$ averaged over our observation period) would imply a reduction in the volatility of price growth of condominiums by up to $0.8 \%$ From Figure 3 we can see that this effect corresponds to the 
interquartile range of Volatility CON across all MS-regions $\left(25^{\text {th }}\right.$ percentile $=1.3 \%, 75^{\text {th }}$ percentile $=2.1 \%$ )

Accounting for the endogeneity of tax policy by excluding the "large” MS-regions in our sample has no notable effect on our estimates for single-family houses (column 3). Strikingly, though, the smoothing effect of the capital gains tax on the price growth volatility of condominiums increases both in statistical and economic terms when we account for endogenous tax policy.

The results reported in Table 5 suggest thus that the taxation of real estate transactions has a limited smoothing effect on house price growth volatility. In particular, we find that only the tax on long-term capital gains (but not its short term penalty component or the transaction tax ) influences the volatility of price growth, and only for condominiums. This limited effect seems reasonable both from a theoretical and empirical perspective. From a theory point of view, the tax on long-term capital gains tax, in comparison to the penalty tax on short-term capital gains, is less likely to induce lock-in effects (Englund 1986). From an empirical point of view, the market for condominiums in Switzerland does seem to be the more volatile market over time than that for single-family houses (cf. Figure 2). Thus it is not surprising that the capital gains tax has a stronger effect in the former than in the latter.

\subsection{Housing demand, taxes and price growth}

In the previous section we examined whether the taxation of real estate capital gains and transaction values reduces the volatility of house price growth, i.e. smoothes both abnormally high and abnormally low price growth. In this section we examine whether the Capital gains tax, Speculation multiplier and Transaction tax prevent excessive price growth in MS-regions which face a strong growth in the demand for housing. The impact of the 
capital gains tax and the Tobin tax under strong housing demand is arguably most interesting from the viewpoint of macroprudential policy.

[Table 6 here]

Table 6 presents our estimates of model [3] in which we relate excessive price growth per MS-region and period to our three tax indicators as well as to the interaction of these indicators with housing demand growth. The variable Demand growth is measured per MSregion and period as Population growth plus per capita Income growth. Results for singlefamily houses (Residual growth SFH) are presented in columns (1-3) while results for condominiums (Residual growth CON) are presented in columns (4-6). For both dependent variables we present a baseline specification (columns 1,4) with the main effects of our tax indicators only, and a main specification which includes their interaction terms with demand growth (columns 2,5). For each dependent variable we also present a specification in which we account for the endogeneity of tax policy to excessive house price growth (columns 3,6).

The results displayed in Table 6 suggest that the capital gains tax dampens excessive price growth in times of strong demand. The interaction term of Capital gains tax * Demand growth displays a significant negative coefficient for both single-family houses and condominiums. Taking into account the positive main effect of Capital gains tax reported in the first row of Table 6, the coefficient estimated for condominiums (Residual growth CON) in column (6) suggests that a $1 \%$ increase in the capital gains tax would have almost no effect on excessive price growth in a MS-region with average demand growth (3.2\% during our observation period). By comparison, in a MS-Region with demand growth of the average plus one standard-deviation (5.6\%) a 1\% increase in the capital gains tax would reduce excessive price growth by $0.03 \%$. The effect of the capital gains tax under such strong demand growth 
is sizeable if we consider the current range of capital gains taxes across Swiss cantons. In 2005 the canton with the lowest capital gains tax was Obwalden (17\%) while that with the highest capital gains tax was Graubünden (50\%). With demand growth of 5.6\% per year (i.e. the average plus one standard deviation), MS-regions in Graubünden would experience 1\% lower price growth per year than MS-regions in Obwalden. In line with our findings in Table 5 the interaction term of Capital gains tax * Demand growth is weaker in economic terms for single-family houses (column 2,3).

In contrast to the tax on long-term capital gains, our results suggest that penalty taxes on short term capital gains fuel excessive house price growth rather than dampen it. Considering excessive price growth of single-family houses we find a significant positive coefficient for the interaction term Speculation multiplier * Demand growth irrespective of whether we account for endogenous tax policy (column 3) or not (column 2). For condominiums we find a significant negative coefficient, of similar economic magnitude, when we account for the endogeneity of tax policy (column 6). These results support theoretical models (Englund, 1986) which suggest that capital gains taxes may fuel excessive price growth by making house owners with short tenure more reluctant to sell their property (lock-in effect).

Finally, we find evidence that a transaction (Tobin) tax also smoothes house prices. The coefficient of Transaction tax * Demand growth estimated in columns $(2,3)$ is negative and significant suggesting that the transaction tax reduces price growth of single-family houses when housing demand is strong. Moreover, while we do not obtain a significant coefficient for Transaction tax * Demand growth in columns $(5,6)$, the main effect of Transaction tax is negative and significant in these models. This finding suggests that the transaction tax dampens price growth of condominiums too, and that this effect is not just limited to periods of strong housing demand. 


\section{Conclusions}

Excessive growth of house prices is seen as one of the major determinants of the recent financial and economic crisis, in the US and in the euro area (e.g. Ireland). Motivated by the search for macroprudential instruments it has been argued that a Tobin tax and a capital gains tax on real-estate sales may dampen the swings in prices in the housing market by "throwing sand in the wheels" of short-term speculation. ${ }^{27}$ We investigate the effect of capital gains taxes and Tobin taxes on house price dynamics, exploiting the variation in tax rates across Swiss cantons, as well as changes in these tax rates with cantons over the last three decades.

We find evidence that higher taxes on longer-term capital gains and higher transaction (Tobin) taxes smooth house price growth. By contrast, we find that a penalty tax on shortterm capital gains fuels excessive price growth when housing demand is strong. Our results suggest that transaction taxes and capital gains taxes are not uniformly suitable as instruments of macroprudential policy. In particular, due to lock-in effects for existing home-owners, the use of penalty taxes on short-term capital gains, as widely applied for example in Switzerland, may be counterproductive to the objective of systemic stability.

\footnotetext{
${ }^{27}$ The OECD has, for instance, expressed a view along these lines. Cf. Fuest et al. (2004).
} 


\section{References}

Ahearne, A.G., J. Ammer, B.M. Doyle, L.S. Kole, R.F. Martin. 2005. House Prices and Monetary Policy: A Cross-Country Study. International Finance Discussion Papers 841. Board of Governors of the Federal Reserve System, Washington, D.C.

Allen, F. and E. Carletti. 2010. Macroeconomic Aspects of Cross-Border Banking. Paper presented at the Cross-Border Banking Workshop. Duisenberg School of Finance, Amsterdam. 1 October 2010.

Bank of England. 2009. The role of macroprudential policy. A Discussion Paper, November.

Bogart, W. T. and W. M. Gentry. 1995. Capital Gains Taxes and Realizations: Evidence from Interstate Comparisons. Review of Economics and Statistics 77(2), May: 267-282.

Bolliger, M. and I. Cecchin (2009). How do Banks set Loan Rates? An Empirical Investigation for Switzerland, memo, Swiss National Bank.

Borio, C. and P. Disyatat. 2009. Unconventional monetary policies: an appraisal. BIS Working Papers No 292, November.

Bourassa, S. C. and M. Hoesli. 2006. Why Do the Swiss Rent? Swiss Finance Institute Research Paper Series N07-04, December 27.

Brülhart, M. and M. Jametti. 2008. Does Tax Competition Tame the Leviathan? University of Lausanne Working paper.

CGFS Papers No 38. 2010. Macroprudential instruments and frameworks: a stocktaking of issues and experiences, May. Committee on the Global Financial System. Bank for International Settlements.

Claessens, S., M. A. Kose, M. E. Terrones. 2008. What Happens During Recessions, Crunches and Busts? IMF Working Paper 08/274, December.

Degen. K. and A. M. Fischer. 2009. Immigration and Swiss House Prices. CEPR Discussion Paper 7583. 
Diamond, P. A. 1975. Inflation and the comprehensive tax base. Journal of Public Economics 4: $227-244$

Englund, P. 1985. Taxation of Capital Gains on Owner-Occupied Homes. European Economic Review 27: 311-334.

Englund, P. 1986. Transaction Costs, Capital Gains Taxes and Housing Demand. Journal of Urban Economics 20: 274-290.

Fuest, C., B. Huber, and S. B. Nielsen. 2004. Capital Gains Taxation and House Price Fluctuations. Department of Economics Copenhagen Business School Working paper $16-2004$

Goodhart, C.A.E. 2009. The Regulatory Response to the Financial Crisis. Edward Elgar Publishing Limited, Cheltenham UK.

Hau, H. 2006. The Role of Transaction Costs for Financial Volatility: Evidence from the Paris Bourse. Journal of the European Economic Association 4(4): 862-890.

Hilbers, P., Q. Lei and L. Zacho. 2001. Real Estate Market Developments and Financial Sector Soundness. IMF Working Paper 01/129, September.

Hoyt, W. H. and S. S. Rosenthal. 1992. Owner-Occupied Housing, Capital Gains, and the Tax Reform Act of 1986. Journal of Urban Economics 32: 119-139.

International Monetary Fund (IMF). 2003. When Bubbles Burst. World Economic Outlook, Washington, D.C., 61-94.

International Monetary Fund (IMF). 2009. Lessons for Monetary Policy from Asset Price Fluctuations. World Economic Outlook, Washington, D.C., 93-120.

Jannsen, N. (2010). National and International Business Cycle Effects of Housing Crises. Applied Economics Quarterly 56(2): 175-206.

Jeanne, O. (2008). Dealing with Credit Booms and Busts: the Case for Prudential Taxation, November. 
Jeanne, O. and A. Korinek. 2010. Managing Credit Booms and Busts: A Pigouvian Taxation Approach. NBER Working Paper 16377, September.

Jordan, Th. J. 2010. A changing role for central banks? Welcome Event Master of Banking and Finance. St. Gallen, 22 September 2010.

Keynes, J. M. 1936. The General Theory of Employment, Interest, and Money. London: Macmillan.

King, M. A. 1977. Public policy and the corporation. Chapman and Hall, London.

Leamer, E. 2007. Housing is the Business Cycle. NBER Working Paper 13428.

Lundborg, P. and P. Skedinger. 1998. Capital gains taxation and residential mobility in Sweden. Journal of Public Economics 67: 399-419.

Lundborg, P. and P. Skedinger. 1999. Transactions Taxes in a Search Model of the Housing Market. Journal of Urban Economics 45: 385-399.

Milne, A. 2009. Macroprudential policy: what can it achieve? Oxford Review of Economic Policy 25(4): 608-629.

Posen, A.S. 2009. Finding the Right Tool for Dealing with Asset Price Booms. Speech to the MPR Monetary Policy and the Markets Conference, London, 1 December 2009.

Reinhart, C.M. and K.S. Rogoff. 2008. Is the 2007 U.S. Sub-Prime Financial Crisis So Different? An International Historical Comparison. NBER Working Paper 13761, January.

Rosen, H. S., K. T. Rosen, and D. Holtz-Eakin. 1984. Housing Tenure, Uncertainty and Taxation. Review of Economics and Statistics 66: 405-416.

Saiz, A. 2007. Immigration and Housing Rents in American Cities. Journal of Urban Economics 61(2): 345-371.

Sheffrin, S. M. and T. M. Turner. 2001. Taxation and House-Price Uncertainty: Some Empirical Estimates. International Tax and Public Finance 8: 621-636. 
Steiner, E. 2010. Estimating a stock-flow model for the Swiss housing market. Swiss National Bank Working Paper 2010-8.

Stiglitz, J. E. 1983. Some Aspects of the Taxation of Capital Gains. Journal of Public Economics 21: 257-294.

Stiglitz, J. E. 1989. Using Tax Policy to Curb Speculative Short-term Trading. Journal of Financial Service Research 3(2-3): 101-115.

Swiss Federal Statistical Office (SFSO). 2004. Eidgenössische Volkszählung 2000 Gebäude, Wohnungen und Wohnverhältnisse. Neuenburg: SFSO.

Swiss Federal Tax Administration (SFTA)

(2010a). Die Einkommenssteuer natürlicher Personen.

(2010b). Die Vermögenssteuer natürlicher Personen.

(2010c). Die Besteuerung der Grundstückgewinne.

(2010d). Die Besteuerung der Kapitalgewinne auf beweglichem Privatvermögen.

(2010e). Die Handänderungssteuer.

Retrieved February 10, from

http://www.estv.admin.ch/dokumentation/00079/00080/00736/index.html?lang=de

Tobin, J. 1978. A Proposal for International Monetary Reform. Eastern Economic Journal 4: 153-159. 
Table 1. Variable definitions and sources

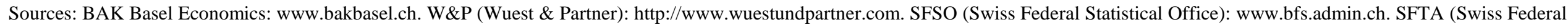
Tax Administration): www.estv.admin.ch.

\begin{tabular}{|c|c|c|c|c|}
\hline Variable name & Definition & Source & Level of observation & Periodicity \\
\hline \multicolumn{5}{|c|}{ House prices } \\
\hline Price growth SFH & $\begin{array}{l}\text { Average annual growth rate of the hedonic transaction price index of single- } \\
\text { family houses. }\end{array}$ & $\mathrm{W} \& \mathrm{P}$ & MS-region & $\begin{array}{r}1985-1989 \text { / 1990-1994 / 1995-1999 / } \\
\text { 2000-2004 / 2005-2009 }\end{array}$ \\
\hline Price growth CON & $\begin{array}{l}\text { Average annual growth rate of the hedonic transaction price index of } \\
\text { condominiums. }\end{array}$ & $\mathrm{W} \& \mathrm{P}$ & MS-region & $\begin{array}{r}1985-1989 \text { / 1990-1994 / 1995-1999 / } \\
2000-2004 \text { / 2005-2009 }\end{array}$ \\
\hline \multicolumn{5}{|c|}{ Taxation of real estate transactions } \\
\hline Capital gains tax & Top marginal gains tax rate if real estate has been held for five years. & $\begin{array}{r}\text { Cantonal tax } \\
\text { authorities, SFTA }\end{array}$ & Canton & 1985 / 1990 / 1995 / 2000 / 2005 \\
\hline Speculation multiplier & $\begin{array}{l}\text { The multiplier by which the Gains tax rate increases if real estate is sold } \\
\text { after less than one year instead of after } 5 \text { years. }\end{array}$ & $\begin{array}{l}\text { Cantonal tax } \\
\text { authorities, SFTA }\end{array}$ & Canton & 1985 / 1990 / 1995 / 2000 / 2005 \\
\hline Transaction tax & Top marginal transaction tax rate. & $\begin{array}{r}\text { Cantonal tax } \\
\text { authorities, SFTA } \\
\end{array}$ & Canton & 1985 / 1990 / 1995 / 2000 / 2005 \\
\hline \multicolumn{5}{|c|}{ Control variables } \\
\hline Population growth & Average annual growth rate of population. & SFSO & MS-region & $\begin{array}{r}1985-1989 / 1990-1994 / 1995-1999 / \\
2000-2004 / 2005-2008\end{array}$ \\
\hline Income growth & Average annual growth rate of per capita income (nominal). & BAK & MS-region & $\begin{array}{r}1985-1989 \text { / 1990-1994 / 1995-1999 / } \\
\text { 2000-2004 / 2005-2008 }\end{array}$ \\
\hline Demand growth & Population growth + Income growth & SFSO, BAK & MS-region & $\begin{array}{r}1985-1989 \text { / 1990-1994 / 1995-1999 / } \\
\text { 2000-2004 / 2005-2008 }\end{array}$ \\
\hline Housing stock growth & $\begin{array}{l}\text { Average annual net growth rate of the stock of dwellings (lagged by one } \\
\text { observation period). }\end{array}$ & SFSO & MS-region & $\begin{array}{r}1985-1989 \text { / 1990-1994 / 1995-1999 / } \\
2000-2004 \text { / 2005-2008 }\end{array}$ \\
\hline Mortgage rate & Mortgage interest rate offered by cantonal banks on new mortgages. & SNB & Canton & $\begin{array}{r}1985-1989 / 1990-1994 \text { / } 1995-1999 / \\
2000-2004 / 2005-2008\end{array}$ \\
\hline Urban & 1= Urban MS-region, 0=Rural MS-region & SFSO & MS-region & 2008 \\
\hline Tourism & Ratio of overnight stays to population per day. & SFSO & MS-region & 1992-2008 \\
\hline Income tax & Average tax rate on annual income of 100 '000 CHF & SFTA & Canton & 1985-2008 \\
\hline
\end{tabular}


Table 2. Summary statistics

This panel reports the (unweighted) mean and standard deviation (in brackets) across the 92 MS-regions in our sample for the periods 1985-1989, 1990-1994, 1995-1999, 2000-2004, 2005-2009 separately and all 5 periods together. Definitions and sources of the variables are provided in Table 1.

\begin{tabular}{|c|c|c|c|c|c|c|}
\hline & 1985-1989 & 1990-1994 & 1995-1999 & 2000-2004 & 2005-2009 & all 5 periods \\
\hline \multicolumn{7}{|l|}{ House prices } \\
\hline Price growth SFH & 3.69 (1.99) & $-0.11(1.44)$ & $-0.22(1.03)$ & $0.93(1.79)$ & $3.94(2.01)$ & $1.65(2.48)$ \\
\hline Price growth CON & $4.97(1.22)$ & $0.08(1.33)$ & $-1.99(1.24)$ & $1.98(1.58)$ & $4.54(2.44)$ & $1.91(3.10)$ \\
\hline \multicolumn{7}{|c|}{ Taxation of real estate transactions } \\
\hline Capital gains tax & $31.17(7.52)$ & $33.21(9.36)$ & 33.87 (8.95) & $33.97(9.02)$ & 32.45 (9.13) & $32.94(8.84)$ \\
\hline Speculation multiplier & $1.41(0.26)$ & $1.38(0.24)$ & $1.43(0.30)$ & $1.43(0.30)$ & $1.52(0.23)$ & $1.43(0.27)$ \\
\hline Transaction tax & $1.86(1.05)$ & $1.84(1.03)$ & $1.84(0.97)$ & $1.76(0.87)$ & $1.60(1.03)$ & $1.78(0.99)$ \\
\hline \multicolumn{7}{|l|}{ Control variables } \\
\hline Population growth & $0.88(0.71)$ & $1.10(0.69)$ & $0.26(0.72)$ & $0.76(0.61)$ & $0.78(0.73)$ & $0.76(0.74)$ \\
\hline Income growth & $5.29(0.89)$ & $3.00(1.08)$ & 1.09 (1.09) & $-0.19(1.45)$ & $3.07(1.48)$ & $2.45(2.24)$ \\
\hline Housing stock growth & $1.67(0.79)$ & $1.70(0.62)$ & $2.05(1.15)$ & $1.23(0.53)$ & $0.70(1.04)$ & $1.47(0.97)$ \\
\hline Mortgage rate & $5.50(0.06)$ & $6.91(0.14)$ & $4.57(0.07)$ & $3.82(0.07)$ & $3.17(0.04)$ & $4.79(1.31)$ \\
\hline Urban & & & & & & $0.13(0.34)$ \\
\hline Tourism & & & & & & $2.89(5.59)$ \\
\hline Income tax & & & & & & $10.75(1.62)$ \\
\hline
\end{tabular}


Table 3. Taxes on real estate gains and transaction values by canton

The table displays the value of the variables Capital gains tax (in \%), Speculation multiplier and Transaction tax (in \%) in 1985 and 2005 for the 21 cantons in the sample. Definitions and sources of the variables are provided in Table 1.

\begin{tabular}{|c|c|c|c|c|c|c|c|}
\hline \multirow[b]{2}{*}{ Canton } & \multirow[b]{2}{*}{ Abbr. } & \multicolumn{2}{|c|}{ Capital gains tax } & \multicolumn{2}{|c|}{ Speculation multiplier } & \multicolumn{2}{|c|}{ Transaction tax } \\
\hline & & 1985 & 2005 & 1985 & 2005 & 1985 & 2005 \\
\hline$\overline{\text { Aargau }}$ & $\overline{A G}$ & 30 & 32 & 1.6 & 1.3 & 0.4 & 0.5 \\
\hline Appenzell I.Rh. & $\mathrm{AI}$ & 38 & 38 & 1.3 & 1.3 & 1.0 & 1.0 \\
\hline Bern & $\mathrm{BE}$ & 39 & 34 & 1.6 & 1.9 & 1.5 & 1.8 \\
\hline Basel-Landschaft & BL & 25 & 25 & 2.0 & 1.8 & 3.0 & 2.5 \\
\hline Basel-Stadt & BS & 32 & 48 & 1.0 & 1.3 & 3.0 & 3.0 \\
\hline Fribourg & FR & 29 & 29 & 1.7 & 1.7 & 4.0 & 3.0 \\
\hline Genève & GE & 20 & 30 & 1.6 & 1.7 & 3.0 & 3.0 \\
\hline Glarus & GL & 29 & 29 & 1.3 & 1.4 & 0.5 & 0.5 \\
\hline Graubünden & GR & 30 & 50 & 1.3 & 1.3 & 1.5 & 1.5 \\
\hline Luzern & LU & 27 & 27 & 1.5 & 1.5 & 1.5 & 1.5 \\
\hline Neuchâtel & $\mathrm{NE}$ & 24 & 40 & 1.7 & 1.6 & 4.0 & 3.3 \\
\hline Nidwalden & NW & 25 & 29 & 1.5 & 1.4 & 1.0 & 1.0 \\
\hline Obwalden & OW & 16 & 17 & 1.4 & 1.4 & 1.5 & 1.5 \\
\hline Schaffhausen & $\mathrm{SH}$ & 48 & 44 & 1.5 & 1.5 & 0.7 & 0.7 \\
\hline Schwyz & $\mathrm{SZ}$ & 27 & 27 & 1.6 & 1.6 & 1.0 & 1.0 \\
\hline Thurgau & TG & 40 & 40 & 1.3 & 1.3 & 1.0 & 1.0 \\
\hline Ticino & $\mathrm{TI}$ & 26 & 26 & 1.4 & 1.2 & 1.1 & 1.1 \\
\hline Uri & UR & 33 & 44 & 1.3 & 1.3 & 0.3 & 0.2 \\
\hline Vaud & VD & 18 & 18 & 1.0 & 1.7 & 3.3 & 3.3 \\
\hline Valais & VS & 40 & 26 & 1.0 & 1.5 & 1.4 & 1.4 \\
\hline Zürich & $\mathrm{ZH}$ & 38 & 38 & 1.6 & 1.6 & 2.0 & 0.0 \\
\hline
\end{tabular}




\section{Table 4. House price growth}

The dependent variables are Price growth SFH and Price growth CON. The time dimension of the panel covers the five periods 1985-1989, 1990-1994, 1995-1999, 2000-2004, 2005-2009. Heteroskedasticity-robust standard errors, clustered by canton are reported in brackets. $* * *, * *, *$ denote significance at the $0.01,0.05$ and $0.10-$ level. Definitions and sources of all variables are provided in Table 1.

\begin{tabular}{lrrrr}
\hline \hline \multicolumn{1}{c}{$\begin{array}{r}\text { Dependent variable: } \\
\text { Model }\end{array}$} & Price growth SFH & $(1)$ & Price growth CON & $(3)$ \\
& None & MS-region & (2) \\
\multicolumn{1}{c}{ Fixed effects: } & 0.579 & 0.604 & 0.756 & MS-region \\
\hline Population growth & {$[0.073]^{* * *}$} & {$[0.085]^{* * *}$} & {$[0.072]^{* * *}$} & 0.778 \\
& 0.705 & 0.924 & 1.39 & {$[0.086]^{* * *}$} \\
Income growth & {$[0.206]^{* * *}$} & {$[0.377]^{* *}$} & {$[0.288]^{* * *}$} & {$[0.475]^{* * *}$} \\
& -0.2 & -0.054 & -0.658 & -0.458 \\
Housing stock growth & {$[0.146]$} & {$[0.294]$} & {$[0.177]^{* * *}$} & {$[0.246]^{*}$} \\
& -0.935 & -1.007 & -1.042 & -1.159 \\
Mortgage rate & {$[0.185]^{* * *}$} & {$[0.246]^{* * *}$} & {$[0.160]^{* * *}$} & {$[0.207]^{* * *}$} \\
& 460 & 460 & 460 & 460 \\
Observations & 0.38 & 0.47 & 0.47 & 0.56 \\
R-squared & 92 & 92 & 92 & 92 \\
Number of MS-regions & 21 & 21 & 21 & 21 \\
Number of Cantons & & & & 92 \\
\hline \hline
\end{tabular}


Table 5. Taxes and the volatility of house price growth

The dependent variables are Volatility SFH and Volatility CON calculated as the mean absolute residuals per MS-region from model (2,4) in Table 4 over all observation periods. All explanatory variables are averaged of our observation period. The models are estimated using MSregion-level data. In columns $(3,6)$ we exclude "large" MS-regions within a canton: We only include cantons with at least 3 MS-regions and MS-regions which do not exceed $20 \%$ of the population of the canton they are located in. Heteroskedasticity-robust standard errors, clustered by canton, are reported in brackets. ${ }^{* * *}, * *, *$ denote significance at the $0.01,0.05$ and 0.10 -level. Definitions and sources of all variables are provided in Table 1.

\begin{tabular}{|c|c|c|c|c|c|c|}
\hline \multirow{2}{*}{$\begin{array}{r}\text { Dependent variable: } \\
\text { Model: }\end{array}$} & \multicolumn{3}{|c|}{ Volatility SFH } & \multicolumn{3}{|c|}{ Volatility CON } \\
\hline & (1) & $(2)$ & (3) & (4) & (5) & (6) \\
\hline Capital gains tax & -0.004 & -0.009 & -0.007 & -0.021 & -0.026 & -0.048 \\
\hline \multirow[t]{2}{*}{ Speculation multiplier } & -0.374 & -0.244 & -0.376 & -0.110 & 0.021 & 0.292 \\
\hline & [0.323] & [0.297] & {$[0.392]$} & [0.308] & [0.292] & [0.423] \\
\hline Transaction tax & -0.071 & 0.026 & 0.035 & -0.129 & -0.073 & -0.137 \\
\hline 'Urban & & [0.232] & {$[0.280]$} & & {$[0.252]^{*}$} & [0.327] \\
\hline \multirow[t]{2}{*}{ Tourism } & & 0 & -0.001 & & 0.002 & 0.017 \\
\hline & & [0.009] & {$[0.009]$} & & [0.013] & {$[0.014]$} \\
\hline \multirow[t]{2}{*}{ Income tax } & & -0.113 & -0.125 & & -0.081 & -0.129 \\
\hline & & [0.075] & {$[0.083]$} & & [0.066] & [0.079] \\
\hline Constant & 2.225 & 3.213 & 3.393 & 2.749 & 3.419 & 4.299 \\
\hline R-squared & 0.04 & 0.12 & 0.16 & 0.07 & 0.16 & 0.20 \\
\hline
\end{tabular}


Table 6. Housing demand, taxes and price growth

The dependent variables are Residual growth SFH and Residual growth CON. The time dimension of the panel covers the five periods 1985-1989, 1990-1994, 1995-1999, 2000-2004, 2005-2009. In columns (1-2, 4-5) we include all MS-regions. In columns(3,6) we include cantons with at least 3 MS-regions and MS-regions which do not exceed 20\% of the population of the canton they are located in. Heteroskedasticity-robust standard errors, clustered by canton, are reported in brackets. ***, **, * denote significance at the 0.01, 0.05 and 0.10-level. Definitions and sources of all variables are provided in Table 1.

\begin{tabular}{|c|c|c|c|c|c|c|}
\hline \multirow{2}{*}{$\begin{array}{r}\text { Dependent variable } \\
\text { Model: }\end{array}$} & \multicolumn{3}{|c|}{ Residual growth SFH } & \multicolumn{3}{|c|}{ Residual growth CON } \\
\hline & $(1)$ & (2) & (3) & $(4)$ & $(5)$ & (6) \\
\hline \multirow[t]{2}{*}{ Capital gains tax } & 0.034 & 0.055 & 0.080 & -0.007 & 0.022 & 0.038 \\
\hline & [0.034] & {$[0.034]$} & {$[0.038] *$} & {$[0.028]$} & [0.034] & [0.042] \\
\hline \multirow[t]{2}{*}{ Speculation multiplier } & 2.949 & 1.952 & 2.033 & 2.039 & 1.281 & 1.018 \\
\hline & [1.784] & {$[1.596]$} & {$[1.464]$} & [1.989] & [2.002] & [1.862] \\
\hline \multirow[t]{2}{*}{ Transaction tax } & -0.627 & -0.246 & -0.386 & -0.335 & -0.464 & -0.527 \\
\hline & {$[0.307]^{*}$} & {$[0.405]$} & {$[0.309]$} & {$[0.220]$} & {$[0.202]^{* *}$} & {$[0.181] * *$} \\
\hline \multicolumn{7}{|l|}{ Demand growth* } \\
\hline \multirow[t]{2}{*}{ Capital gains tax } & & -0.007 & -0.008 & & -0.01 & -0.012 \\
\hline & & {$[0.003]^{*}$} & {$[0.002]^{* *}$} & & {$[0.004]^{* * *}$} & {$[0.004]^{* *}$} \\
\hline \multirow[t]{2}{*}{ Speculation multiplier } & & 0.302 & 0.348 & & 0.226 & 0.341 \\
\hline & & {$[0.114]^{* *}$} & {$[0.075]^{* * *}$} & & [0.139] & {$[0.152]^{*}$} \\
\hline \multirow{2}{*}{ Transaction tax } & & -0.094 & -0.108 & & 0.019 & -0.018 \\
\hline & & {$[0.043]^{* *}$} & {$[0.035]^{* *}$} & & {$[0.044]$} & [0.044] \\
\hline Method & OLS & OLS: & OLS & OLS & OLS & OLS \\
\hline Fixed effects & Canton & Canton & Canton & Canton & Canton & Canton \\
\hline R-squared & 0.01 & 0.04 & 0.06 & 0.01 & 0.02 & 0.04 \\
\hline Observations & 460 & 460 & 310 & 460 & 460 & 310 \\
\hline Number of MS-regions & 92 & 92 & 62 & 92 & 92 & 62 \\
\hline Number of Cantons & 21 & 21 & 10 & 21 & 21 & 10 \\
\hline
\end{tabular}




\section{Figure 1. House price growth by period and MS-region}

This figure displays box plots for the variables Price growth SFH and Price growth CON for the five periods 1985-1989, 19901994, 1995-1999, 2000-2004 and 2005-2009. For each period the figure shows the distribution across MS-regions. Each box starts at the lower quartil (25th percentile) and ends at the upper quartil (75th percentile). The line inside the box indicates the median. The upper and lower adjacent values are defined as the 75th (25th) percentiles plus (minus) 1.5 times the size of the box (75th percentile 25th percentiles). Outside values are represented by dots.

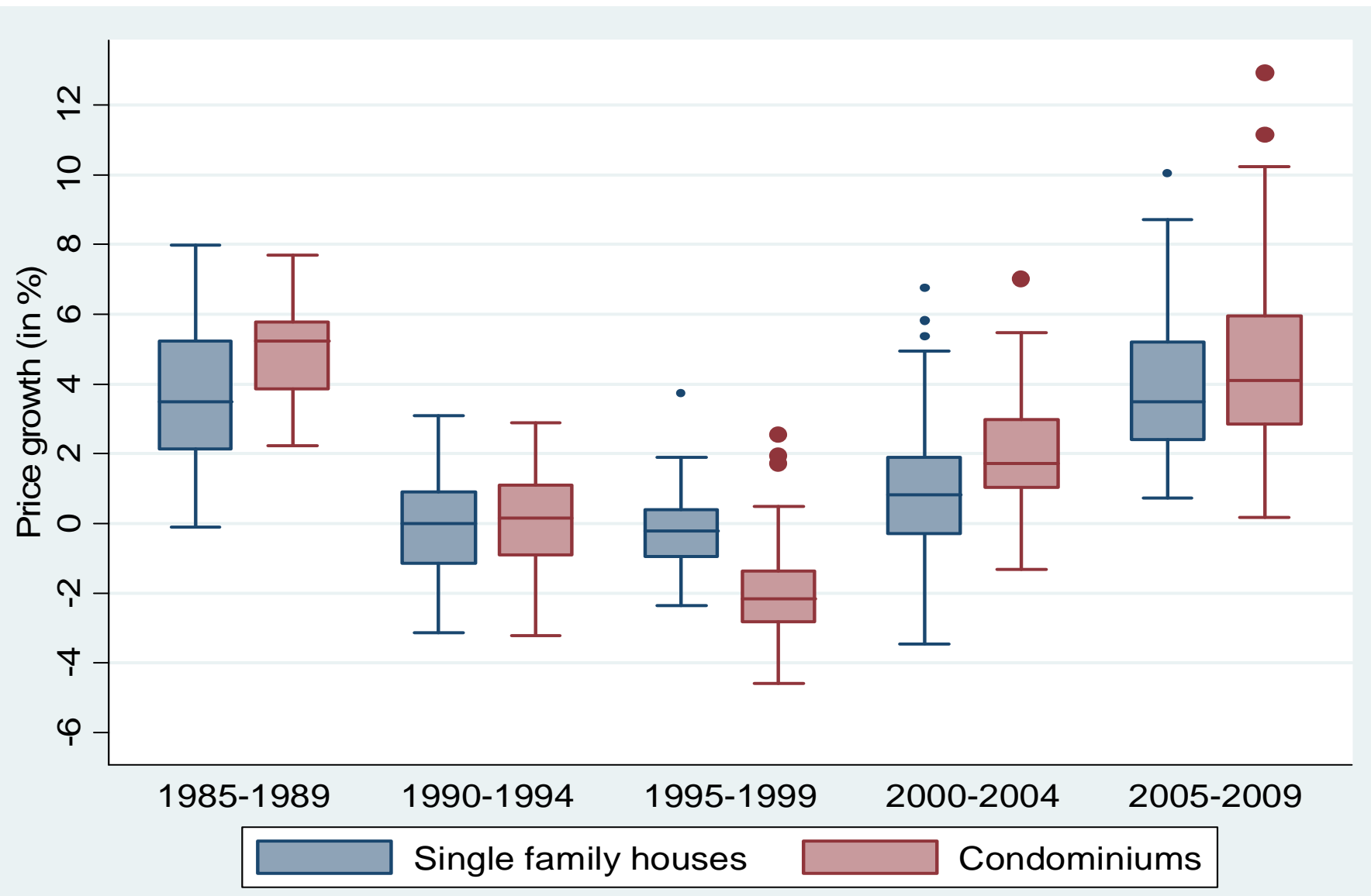


Figure 2. Abnormal house price growth by period and MS-region

This figure displays box plots for the variables Residual growth SFH and Residual growth CON for the five periods 1985-1989, 1990-1994, 1995-1999, 2000-2004 and 2005-2009. For each period the figure shows the distribution across MS-regions. Each box starts at the lower quartil (25th percentile) and ends at the upper quartil (75th percentile). The line inside the box indicates the median. The upper and lower adjacent values are defined as the 75th (25th) percentiles plus (minus) 1.5 times the size of the box (75th percentile - 25th percentiles). Outside values are represented by dots.

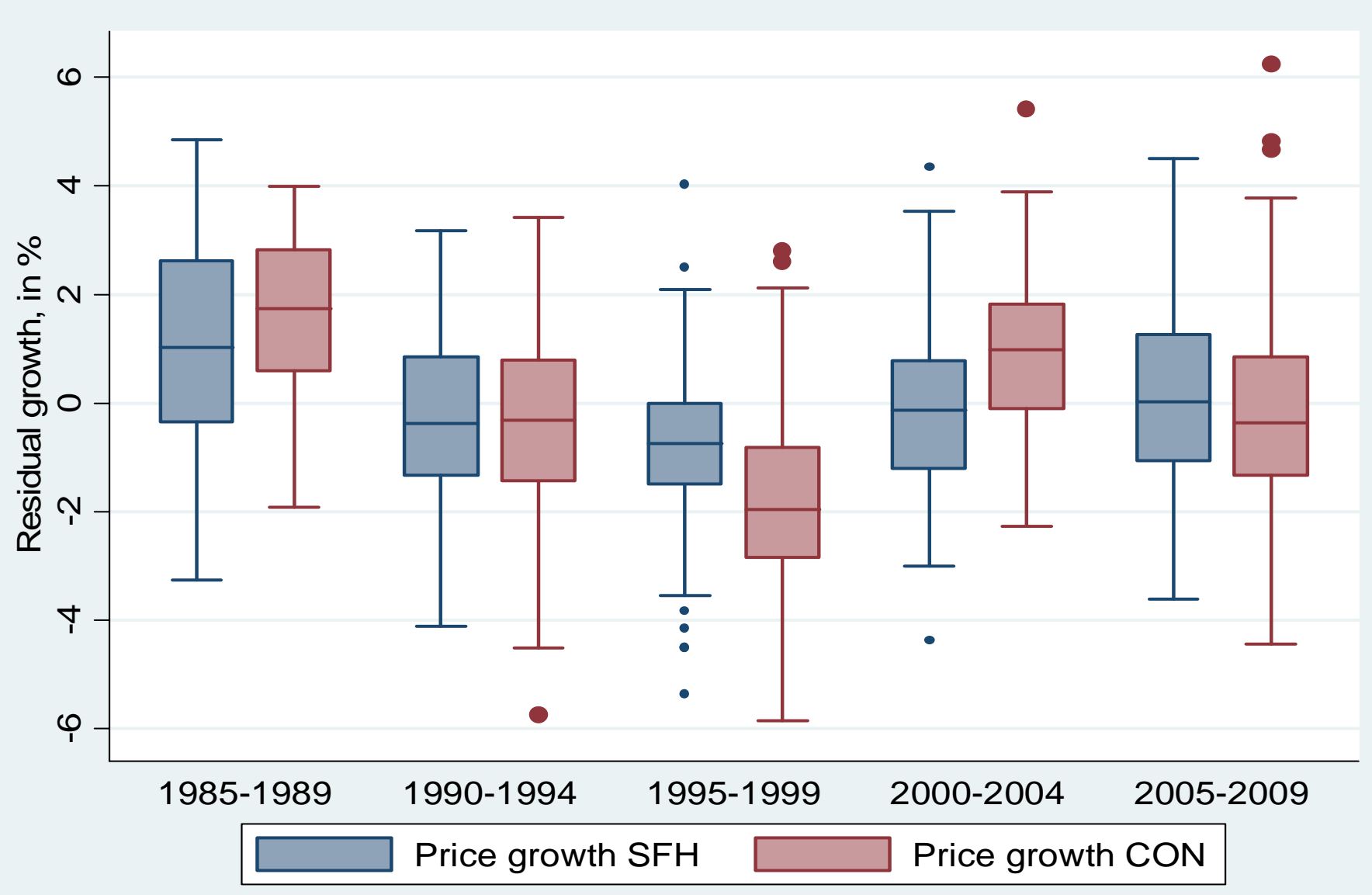


Figure 3. Volatility of house price growth by MS-region

This figure displays box plots for the cross-sectional variables Volatility SFH and Volatility CON across MS-regions. Each box starts at the lower quartil (25th percentile) and ends at the upper quartil (75th percentile). The line inside the box indicates the median. The upper and lower adjacent values are defined as the 75th (25th) percentiles plus (minus) 1.5 times the size of the box (75th percentile - 25th percentiles). Outside values are represented by dots.

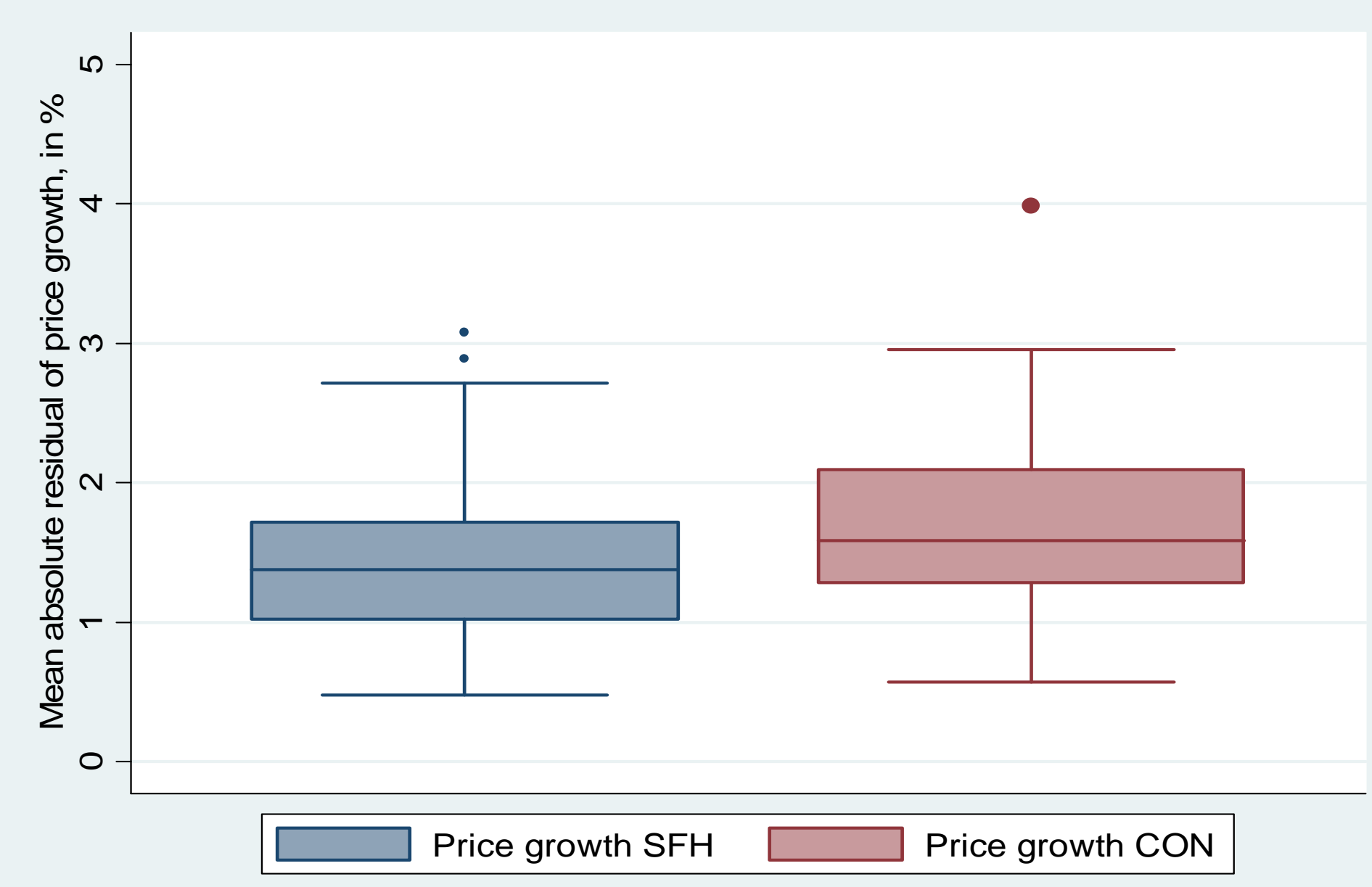




\section{Appendix A1. Cantons and MS-regions}

This figure displays the 26 cantons and the 106 MS-regions in Switzerland. Source: SFSO.

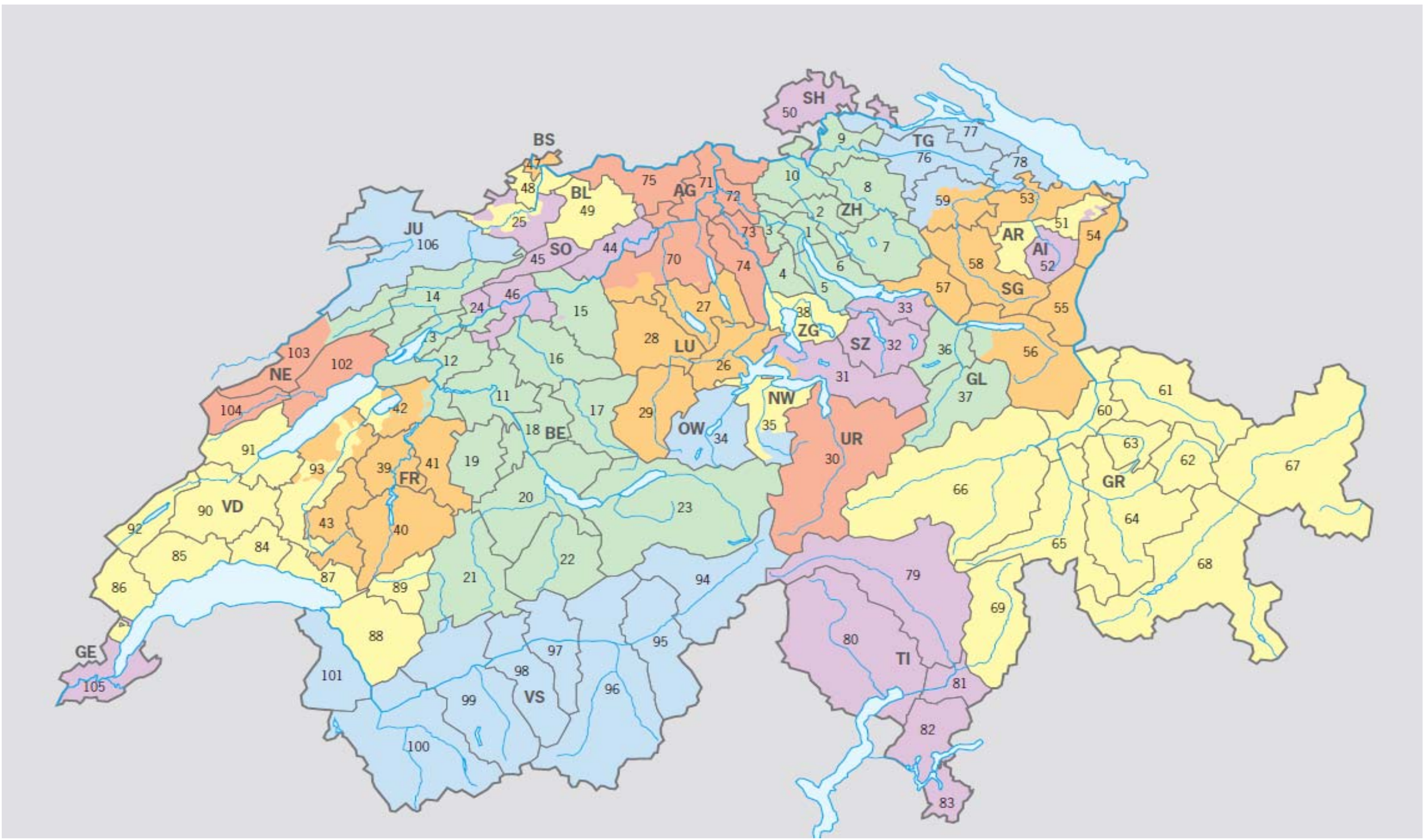


Appendix A1. Cantons and MS-regions

The table lists the 106 MS-regions and their attribution to a canton. Note that information on the attribution of communes to MS-regions and cantons is available. In 14 MS-regions communes belong to two or more cantons. These MS-regions have been assigned to the canton that covers the majority of communes. Source: SFSO.

\begin{tabular}{|c|c|c|c|c|c|c|c|}
\hline Canton & Abbr. & MS-region & MS-region nb. & Canton & Abbr. & MS-region & MS-region nb. \\
\hline \multirow[t]{10}{*}{ Zürich } & \multirow[t]{10}{*}{$\mathrm{ZH}$} & Zürich & 1 & \multirow[t]{7}{*}{ St.Gallen } & \multirow[t]{7}{*}{ SG } & St.Gallen & 53 \\
\hline & & Glattal-Furttal & 2 & & & Rheintal & 54 \\
\hline & & Limmattal & 3 & & & Werdenberg & 55 \\
\hline & & Knonaueramt & 4 & & & Sarganserland & 56 \\
\hline & & Zimmerberg & 5 & & & Linthgebiet & 57 \\
\hline & & Pfannenstiel & 6 & & & Toggenburg & 58 \\
\hline & & Zürcher Oberland & 7 & & & Wil & 59 \\
\hline & & Winterthur & 8 & \multirow[t]{10}{*}{ Graubünden } & \multirow[t]{10}{*}{ GR } & Chur & 60 \\
\hline & & Weinland & 9 & & & Prättigau & 61 \\
\hline & & Zürcher Unterland & 10 & & & Davos & 62 \\
\hline \multirow[t]{13}{*}{ Bern } & \multirow[t]{13}{*}{$\mathrm{BE}$} & Bern & 11 & & & Schanfigg & 63 \\
\hline & & Erlach-Seeland & 12 & & & Mittelbünden & 64 \\
\hline & & Biel/Bienne & 13 & & & Viamala & 65 \\
\hline & & Jura bernois & 14 & & & Surselva & 66 \\
\hline & & Oberaargau & 15 & & & Engiadina Bassa & 67 \\
\hline & & Burgdorf & 16 & & & Oberengadin & 68 \\
\hline & & Oberes Emmental & 17 & & & Mesolcina & 69 \\
\hline & & Aaretal & 18 & \multirow[t]{6}{*}{ Aargau } & \multirow[t]{6}{*}{$\mathrm{AG}$} & Aarau & 70 \\
\hline & & Schwarzwasser & 19 & & & Brugg-Zurzach & 71 \\
\hline & & Thun & 20 & & & Baden & 72 \\
\hline & & Saanen-Obersimmental & 21 & & & Mutschellen & 73 \\
\hline & & Kandertal & 22 & & & Freiamt & 74 \\
\hline & & Oberland-Ost & 23 & & & Fricktal & 75 \\
\hline \multirow[t]{4}{*}{ Luzern } & \multirow[t]{4}{*}{$\overline{L U}$} & Luzern & 26 & \multirow[t]{3}{*}{ Thurgau } & \multirow[t]{3}{*}{ TG } & Thurtal & 76 \\
\hline & & Sursee-Seetal & 27 & & & Untersee & 77 \\
\hline & & Willisau & 28 & & & Oberthurgau & 78 \\
\hline & & Entlebuch & 29 & \multirow[t]{5}{*}{ Ticino } & \multirow[t]{5}{*}{ TI } & Tre Valli & 79 \\
\hline Uri & UR & Uri & 30 & & & Locarno & 80 \\
\hline \multirow[t]{3}{*}{ Schwyz } & \multirow[t]{3}{*}{$\mathrm{SZ}$} & Innerschwyz & 31 & & & Bellinzona & 81 \\
\hline & & Einsiedeln & 32 & & & Lugano & 82 \\
\hline & & March & 33 & & & Mendrisio & 83 \\
\hline Obwalden & OW & Sarneraatal & 34 & Vaud & VD & Lausanne & 84 \\
\hline Nidwalden & NW & Nidwalden & 35 & & & Morges & 85 \\
\hline Glarus & GL & Glarner Unterland & 36 & & & Nyon & 86 \\
\hline & & Glarner Hinterland & 37 & & & Vevey & 87 \\
\hline Zug & ZG & Zug & 38 & & & Aigle & 88 \\
\hline Fribourg & FR & La Sarine & 39 & & & Pays d'Enhaut & 89 \\
\hline & & La Gruyère & 40 & & & Gros-de-Vaud & 90 \\
\hline & & Sense & 41 & & & Yverdon & 91 \\
\hline & & Murten/Morat & 42 & & & La Vallée & 92 \\
\hline & & Glâne-Veveyse & 43 & & & La Broye & 93 \\
\hline Solothurn & SO & Grenchen & 24 & Valais & VS & Goms & 94 \\
\hline & & Olten & 44 & & & Brig & 95 \\
\hline & & Thal & 45 & & & Visp & 96 \\
\hline & & Solothurn & 46 & & & Leuk & 97 \\
\hline Basel-Stadt & BS & Basel-Stadt & 47 & & & Sierre & 98 \\
\hline Basel-Landschaft & $\mathrm{BL}$ & Laufental & 25 & & & Sion & 99 \\
\hline & & Unteres Baselbiet & 48 & & & Martigny & 100 \\
\hline & & Oberes Baselbiet & 49 & & & Monthey & 101 \\
\hline Schaffhausen & $\mathrm{SH}$ & Schaffhausen & 50 & Neuchâtel & $\mathrm{NE}$ & Neuchâtel & 102 \\
\hline Appenzell & $\mathrm{AR}$ & Appenzell A.Rh. & 51 & & & La Chaux-de-Fonds & 103 \\
\hline Ausserrhoden & & & & & & Val-de-Travers & 104 \\
\hline Appenzell & $\mathrm{AI}$ & Appenzell I.Rh. & 52 & Genève & GE & Genève & 105 \\
\hline Innerrhoden & & & & Jura & $\mathrm{JU}$ & Jura & 106 \\
\hline
\end{tabular}


Appendix A2. Tax regimes by canton

This table provides an overview of the current (2010) tax regimes of the real-estate capital gains tax and transaction tax by canton. For the capital gains tax Taxing authority indicates by who the tax is levied. Taxation of accumulated gains indicates whether all realized gains within a year are accumulated or taxed separately. If real estate was owner-occupied and the proceeds of selling it are reinvested within a certain time period in owner-occupied housing then taxation is postponed (Postponement upon reinvestment). In GE the tax is reimbursed instead of postponed. The tax is also postponed in the case of inheritance (except in NE and GE) and donation. In some cantons the capital gains tax rate increases with the size of the gain (Progression gain) and in all cantons the rate depends on the holding duration (Degression holding duration). Some cantons have a base tax rate which is multiplied every year by a cantonal only or a cantonal, municipal and a parish-factor (Annual multiplier). The tax rate may vary across municipalities (Variation across municipalities ). The transaction tax rate is Proportional in transaction value, Progressive in transaction value or is a Fixed fee. The transaction tax rate does not vary with the holding duration. The last column indicates whether there is a reduced transaction tax rate or no tax for certain types of transactions (for example transfers within family) (Exemptions ). In cantons where taxes vary across municipalities the tax rate of the major city has been used. The sources are the cantonal tax authorities and the SFTA. * In Zurich the transfer tax has been abolished per January 2005 and in Schwyz per January 2009. ** For gains from owneroccupied housing the tax is $30 \%$ independent of the holding duration.

\begin{tabular}{|c|c|c|c|c|c|c|c|c|c|c|c|c|c|c|c|c|c|c|c|c|}
\hline Canton & Abbr. & 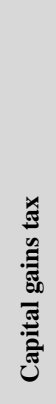 & 总 & 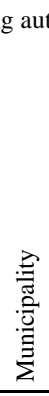 & 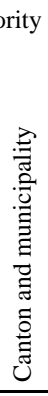 & 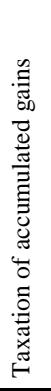 & 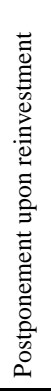 & 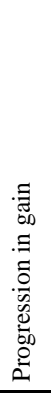 & 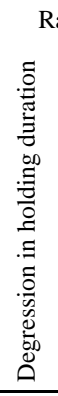 & 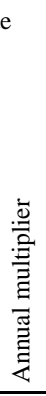 & 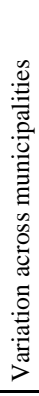 & & 总 & 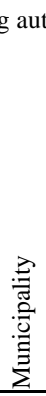 & 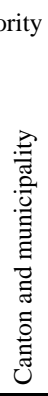 & 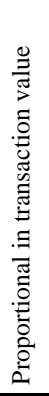 & 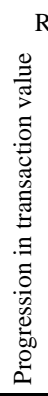 & 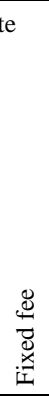 & 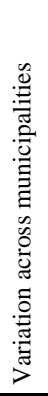 & 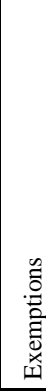 \\
\hline Aargau & $\mathrm{AG}$ & & $\mathrm{x}$ & 0 & 0 & 0 & $\mathrm{x}$ & 0 & $\mathrm{x}$ & 0 & o & & $\mathrm{x}$ & 0 & 0 & $\mathrm{x}$ & 0 & 0 & o & $\mathrm{x}$ \\
\hline Appenzell I.Rh. & $\mathrm{AI}$ & & $\mathrm{x}$ & 0 & o & o & $\mathrm{x}$ & $\mathrm{x}$ & $\mathrm{x}$ & o & o & & $\mathrm{x}$ & o & 0 & $\mathrm{x}$ & 0 & o & o & $\mathrm{x}$ \\
\hline Appenzell A.Rh. & AR & & $\mathrm{x}$ & 0 & 0 & 0 & $\mathrm{x}$ & 0 & $\mathrm{x}$ & o & o & & o & $\mathrm{x}$ & o & $\mathrm{x}$ & 0 & 0 & $\mathrm{x}$ & $\mathrm{x}$ \\
\hline Bern & $\mathrm{BE}$ & & 0 & 0 & $\mathrm{x}$ & $\mathrm{x}$ & $\mathrm{x}$ & $\mathrm{x}$ & $\mathrm{x}$ & $\mathrm{x}$ & $\mathrm{x}$ & & $\mathrm{x}$ & 0 & 0 & $\mathrm{x}$ & 0 & 0 & 0 & $\mathrm{x}$ \\
\hline Basel-Landschaft & BL & & $\mathrm{x}$ & 0 & o & $\mathrm{x}$ & $\mathrm{x}$ & $\mathrm{x}$ & $\mathrm{x}$ & 0 & o & & $\mathrm{x}$ & 0 & 0 & $\mathrm{x}$ & 0 & o & o & $\mathrm{x}$ \\
\hline Basel-Stadt & BS & & o & 0 & $\mathrm{x}$ & o & $\mathrm{x}$ & o & $\mathrm{x}^{* *}$ & o & $\mathrm{x}$ & & $\mathrm{x}$ & o & o & $\mathrm{x}$ & o & 0 & o & $\mathrm{x}$ \\
\hline Fribourg & FR & & 0 & 0 & $\mathrm{x}$ & o & $\mathrm{x}$ & 0 & $\mathrm{x}$ & o & o & & 0 & 0 & $\mathrm{x}$ & $\mathrm{x}$ & 0 & o & $\mathrm{x}$ & $\mathrm{x}$ \\
\hline Genève & GE & & $\mathrm{x}$ & 0 & o & o & o & o & $\mathrm{x}$ & o & o & & $\mathrm{x}$ & o & o & $\mathrm{x}$ & o & o & o & $\mathrm{x}$ \\
\hline Glarus & GL & & $\mathrm{x}$ & 0 & o & o & $\mathrm{x}$ & $\mathrm{x}$ & $\mathrm{x}$ & 0 & o & & $\mathrm{x}$ & 0 & 0 & $\mathrm{x}$ & 0 & 0 & o & $\mathrm{x}$ \\
\hline Graubünden & GR & & o & 0 & $\mathrm{x}$ & $\mathrm{x}$ & $\mathrm{x}$ & $\mathrm{x}$ & $\mathrm{x}$ & o & $\mathrm{x}$ & & o & $\mathrm{x}$ & o & $\mathrm{x}$ & o & o & $\mathrm{x}$ & $\mathrm{x}$ \\
\hline Jura & $\mathrm{JU}$ & & o & 0 & $\mathrm{x}$ & $\mathrm{x}$ & $\mathrm{x}$ & $\mathrm{x}$ & $\mathrm{x}$ & $\mathrm{x}$ & $\mathrm{x}$ & & $\mathrm{x}$ & o & o & $\mathrm{x}$ & o & o & o & $\mathrm{x}$ \\
\hline Luzern & $\mathrm{LU}$ & & $\mathrm{x}$ & 0 & 0 & o & $\mathrm{x}$ & $\mathrm{x}$ & $\mathrm{x}$ & $\mathrm{x}$ & o & & $\mathrm{x}$ & 0 & 0 & $\mathrm{x}$ & o & 0 & o & $\mathrm{x}$ \\
\hline Neuchâtel & $\mathrm{NE}$ & & $\mathrm{x}$ & 0 & o & o & $\mathrm{x}$ & $\mathrm{x}$ & $\mathrm{x}$ & o & o & & $\mathrm{x}$ & 0 & o & $\mathrm{x}$ & o & o & o & $\mathrm{x}$ \\
\hline Nidwalden & NW & & $\mathrm{x}$ & 0 & o & o & $\mathrm{x}$ & o & $\mathrm{x}$ & 0 & 0 & & $\mathrm{x}$ & o & o & $\mathrm{x}$ & 0 & 0 & o & $\mathrm{x}$ \\
\hline Obwalden & OW & & $\mathrm{x}$ & 0 & o & $\mathrm{x}$ & $\mathrm{x}$ & 0 & $\mathrm{x}$ & $\mathrm{x}$ & $\mathrm{x}$ & & $\mathrm{x}$ & 0 & o & $\mathrm{x}$ & o & 0 & o & $\mathrm{x}$ \\
\hline St.Gallen & SG & & $\mathrm{x}$ & 0 & o & o & $\mathrm{x}$ & $\mathrm{x}$ & $\mathrm{x}$ & $\mathrm{x}$ & o & & o & $\mathrm{x}$ & o & $\mathrm{x}$ & 0 & 0 & o & $\mathrm{x}$ \\
\hline Schaffhausen & $\mathrm{SH}$ & & 0 & 0 & $\mathrm{x}$ & o & $\mathrm{x}$ & $\mathrm{x}$ & $\mathrm{x}$ & $\mathrm{x}$ & $\mathrm{x}$ & & $\mathrm{x}$ & 0 & 0 & $\mathrm{x}$ & 0 & 0 & o & $\mathrm{x}$ \\
\hline Solothurn & SO & & $\mathrm{x}$ & 0 & o & o & $\mathrm{x}$ & $\mathrm{x}$ & $\mathrm{x}$ & $\mathrm{x}$ & $\mathrm{x}$ & & $\mathrm{x}$ & o & o & $\mathrm{x}$ & o & 0 & o & $\mathrm{x}$ \\
\hline Schwyz* & SZ & & $\mathrm{x}$ & 0 & 0 & $\mathrm{x}$ & $\mathrm{x}$ & $\mathrm{x}$ & $\mathrm{x}$ & 0 & o & & - & - & - & - & - & - & - & - \\
\hline Thurgau & TG & & $\mathrm{x}$ & 0 & o & o & $\mathrm{x}$ & 0 & $\mathrm{x}$ & o & o & & $\mathrm{x}$ & 0 & o & $\mathrm{x}$ & 0 & 0 & o & $\mathrm{x}$ \\
\hline Ticino & TI & & $\mathrm{x}$ & 0 & o & o & $\mathrm{x}$ & o & $\mathrm{x}$ & o & o & & $\mathrm{x}$ & o & o & o & $\mathrm{x}$ & o & o & $\mathrm{x}$ \\
\hline Uri & UR & & $\mathrm{x}$ & 0 & o & o & $\mathrm{x}$ & $\mathrm{x}$ & $\mathrm{x}$ & 0 & o & & $\mathrm{x}$ & 0 & o & o & $\mathrm{x}$ & 0 & o & o \\
\hline Vaud & VD & & $\mathrm{x}$ & 0 & o & o & $\mathrm{x}$ & 0 & $\mathrm{x}$ & 0 & o & & 0 & 0 & $\mathrm{x}$ & $\mathrm{x}$ & 0 & o & $\mathrm{x}$ & $\mathrm{x}$ \\
\hline Valais & VS & & $\mathrm{x}$ & 0 & o & o & $\mathrm{x}$ & $\mathrm{x}$ & $\mathrm{x}$ & 0 & o & & $\mathrm{x}$ & 0 & 0 & 0 & $\mathrm{x}$ & o & o & o \\
\hline Zug & $\mathrm{ZG}$ & & o & $\mathrm{x}$ & o & o & $\mathrm{x}$ & $\mathrm{x}$ & $\mathrm{x}$ & o & o & & $\mathrm{x}$ & o & o & $\mathrm{x}$ & o & $\mathrm{x}$ & o & o \\
\hline Zürich* & $\mathrm{ZH}$ & & 0 & $\mathrm{x}$ & 0 & 0 & $\mathrm{x}$ & $\mathrm{x}$ & $\mathrm{x}$ & 0 & 0 & & - & - & - & - & - & - & - & - \\
\hline
\end{tabular}

